University of Nebraska - Lincoln

DigitalCommons@University of Nebraska - Lincoln

Publications, Agencies and Staff of the U.S.

Department of Commerce

U.S. Department of Commerce

2012

\title{
The development of a new optical total suspended matter algorithm for the Chesapeake Bay
}

\author{
Michael Ondrusek \\ NOAA/NESDIS/STAR/SOCD, michael.ondrusek@noaa.gov \\ Eric Stengel \\ NOAA/NESDIS/STAR/SOCD \\ Christopher Kinkade \\ NOAA/NOS \\ Ronald Vogel \\ NOAA/NESDIS/STAR/SOCD \\ Phillip Keegstra \\ NOAA/NESDIS/STAR/SOCD \\ See next page for additional authors
}

Follow this and additional works at: https://digitalcommons.unl.edu/usdeptcommercepub

Part of the Environmental Sciences Commons

Ondrusek, Michael; Stengel, Eric; Kinkade, Christopher; Vogel, Ronald; Keegstra, Phillip; Hunter, Craig; and Kim, Chunai, "The development of a new optical total suspended matter algorithm for the Chesapeake Bay" (2012). Publications, Agencies and Staff of the U.S. Department of Commerce. 351.

https://digitalcommons.unl.edu/usdeptcommercepub/351

This Article is brought to you for free and open access by the U.S. Department of Commerce at DigitalCommons@University of Nebraska - Lincoln. It has been accepted for inclusion in Publications, Agencies and Staff of the U.S. Department of Commerce by an authorized administrator of DigitalCommons@University of Nebraska - Lincoln. 


\section{Authors}

Michael Ondrusek, Eric Stengel, Christopher Kinkade, Ronald Vogel, Phillip Keegstra, Craig Hunter, and Chunai Kim 


\title{
The development of a new optical total suspended matter algorithm for the Chesapeake Bay
}

\author{
Michael. Ondrusek ${ }^{\text {a,* }}$, Eric. Stengel a , Christopher.S. Kinkade ${ }^{\text {b }}$, Ronald.L. Vogel ${ }^{\text {c }}$, Phillip. Keegstra ${ }^{\text {d, }}$ \\ Craig. Hunter ${ }^{\mathrm{e}}$, Chunai. Kim ${ }^{\mathrm{f}}$ \\ a NOAA/NESDIS/STAR/SOCD, Camp Springs, MD, USA \\ b NOAA/NOS, Coastal Services Center, Annapolis, MD, USA \\ c SM Resources Corp., NOAA/NESDIS/STAR/SOCD, Camp Springs, MD, USA \\ d SP Systems Inc. NOAA/NESDIS/STAR/SOCD, Camp Springs, MD, USA \\ e Moss Landing Marine Laboratory, Moss Landing, CA, USA \\ ${ }^{\mathrm{f}}$ Riverside Technology, Inc., NOAA/NESDIS/STAR/SOCD, Camp Springs, MD, USA
}

\section{A R T I C L E I N F O}

\section{Article history:}

Received 23 February 2011

Received in revised form 15 December 2011

Accepted 22 December 2011

Available online 26 January 2012

\section{Keywords:}

Chesapeake Bay

Water-leaving radiance

TSM

Remote sensing

\begin{abstract}
A B S T R A C T
Sediment loading is one of the primary threats to the health of the Chesapeake Bay. We have developed a high resolution $(250 \mathrm{~m})$ ocean color satellite tool to monitor sediment concentrations in the Bay. In situ optical and sediment sampling is used to develop a total suspended matter (TSM) algorithm for the Chesapeake Bay. The Coastal Optical Characterization Experiment (COCE) is part of an ongoing effort to optically characterize processes and to develop regional remote sensing ocean color algorithms in the coastal waters. The goal is to characterize sediment concentrations and to develop a tool to track plumes cascading down the Bay following heavy rainfall events. Background TSM concentrations in the Chesapeake Bay Watershed can also be characterized. The plumes can have potentially devastating effects on the Chesapeake Bay's fragile ecosystem by increasing nutrient loads, depositing sediments, and decreasing salinity and light levels. Sampling took place throughout 2006 to 2008 in the upper and mid portions of the Chesapeake Bay. Measurements of TSM, chlorophyll a (Chl), and hyperspectral optics were collected. The optical measurements included above water surface irradiance $\left(E_{s}(\lambda)\right.$ ), in-water downwelling irradiance $\left(E_{d}(\lambda)\right)$ and in-water upwelling radiance $\left(L_{u}(\lambda)\right)$. These optical data were used to analyze the performance and utility of the Moderate Resolution Imaging Spectroradiometer (MODIS) Aqua Band $1(645 \mathrm{~nm})$ for use as a TSM monitoring tool. From the optical measurements we have derived a 3rd order polynomial regression of TSM to normalized water-leaving radiance $\left(r^{2}=0.79\right)$ to form an algorithm that quantitatively relates TSM to the MODIS $250 \mathrm{~m}$ resolution band $1(645 \mathrm{~nm})$. The algorithm performance was validated (a mean percent difference of $-4.2 \%$ ) against 270 total suspended solids samples collected by the Chesapeake Bay Program during routine water quality monitoring of the Chesapeake Bay environment. The TSM algorithm tool is then used to demonstrate monitoring of significant runoff events that occurred in June, 2006 and March, 2008. In addition, the utility of the Chesapeake Bay TSM product is demonstrated by describing regional and seasonal variations in sediment concentrations throughout the Chesapeake Bay for 2009. Mean concentrations ranged from $11.55 \mathrm{mg} / \mathrm{l}$ in the upper Chesapeake Bay winter season to $6.37 \mathrm{mg} / \mathrm{l}$ in the middle Chesapeake Bay spring season. These remote sensing tools can be valuable instruments in the detection and tracking of runoff events and background concentration for monitoring the health and recovery of the Chesapeake Bay.
\end{abstract}

Published by Elsevier Inc.

\section{Introduction}

The Chesapeake Bay is the nation's largest estuary, with a watershed covering 64,000 square miles. The population of this watershed has doubled since 1950 , to 16.8 million people. As a result of this population pressure and its associated urban and agricultural land use/land cover, significant runoff of sediments and nutrients has degraded the health

* Corresponding author at: NOAA/NESDIS/STAR/SCOD, 5200 Auth Rd., Camp Springs, MD 20714, USA. Tel.: +1 3017638102.

E-mail address: michael.ondrusek@noaa.gov (M. Ondrusek). of the complex Chesapeake Bay ecosystem (Kemp et al., 2005; Saenger et al., 2008; Williams et al., 2009, 2010). Increased nutrient loads result in algal blooms, which when they decay, microbial degradation causes oxygen depletion resulting in hypoxic conditions (Diaz \& Rosenberg, 2008; Kemp et al., 2005). High chromophoric dissolved organic matter (CDOM) and sediment loads can reduce water clarity and block radiation necessary for submerged aquatic vegetation (SAV) growth. High sedimentation rates, in addition to reducing water quality, also reduce benthic habitat availability for oysters and other organisms.

Recently, an Executive Order (13508; Chesapeake Bay Protection and Restoration) called for improved monitoring of Chesapeake waters 
to aid restoration efforts. A component of the Chesapeake Bay Executive Order Action Plan (available at http://executiveorder.chesapeakebay. net/) is to define and regulate Total Maximum Daily Loads (TMDL) of nutrients and sediments into the Bay. The sources of sediments and nutrients can be runoff events (Langland \& Cronin, 2003), erosion (Yarbro et al., 1983), resuspension (Sanford et al., 1991; Wright et al., 1997) or non-point specific sources that flow into the Chesapeake Bay from all shorelines or tributaries. While chemical pollutants can have a large non point specific source (Karuppiah \& Gupta, 1996), sediments loads can be maximal during large runoff events (Langland \& Cronin, 2003). Monitoring these inputs can be problematic and satellite remote sensing techniques are one set of observations that can support and supplement current in-situ sampling and modeling efforts.

Sediment, nutrient, and CDOM inputs affect the optical characteristics of estuarine waters, making ocean color (both in-situ and remotely sensed) a good tool to monitor these runoff processes. When trying to characterize runoff events, no single monitoring approach can cover all the scales of variability needed to accurately determine the spatial and temporal extent of the event well enough to quantify the sediment load into the Chesapeake Bay. Shipboard measurements lack temporal and spatial density. Buoys provide good temporal resolution at one location but are difficult to extrapolate in the horizontal. An integrated sampling approach is the best approach to measure all scales of runoff events when determining sediment loads in coastal waters (Warrick et al., 2007). Satellite estimations of suspended material can augment traditional shipboard transects and buoy measurements.

Open-ocean remote sensing algorithms have traditionally not performed well in the optically complex estuarine waters like the Chesapeake Bay (Mobley et al., 2004; Tzortziou et al., 2007). Also, in such estuaries, $1 \mathrm{~km}$ spatial resolution satellite data has limited utility where many of the features and waterways of interest fall within $1 \mathrm{~km}$ of shore. In addition, many surface expressions of water column features in these dynamic regions display variability at scales less than $1 \mathrm{~km}$. Chen et al. (2007) and Hu et al. (2004) demonstrated that the quality of the high spatial resolution MODIS land band at $645 \mathrm{~nm}$ and $250 \mathrm{~m}$ resolution was adequate for producing remote sensing products of coastal waters. Specific, regional, and high resolution remote sensing algorithms have been developed to measure sediments and TSM (Doerffer \& Schiller, 2007; Doxaran et al., 2009; Hu et al., 2004; Miller \& McKee, 2004; Petus et al., 2010; Rodríguez-Guzmán \& GilbesSantaella, 2009; Stumpf, 1988). These algorithms range from linear relationships developed between satellite measured remote sensing reflectance and total suspended matter in coastal US waters (Miller \& McKee, 2004) to regional specific algorithms developed specifically for the coastal Puerto Rican waters using in situ measured radiances and TSM (Rodríguez-Guzmán \& Gilbes-Santaella, 2009).

This paper discusses the development of a high-resolution MODIS ocean color TSM algorithm for the Chesapeake Bay. The algorithm is validated against independently measured total suspended solid values collected during 2009 by the Chesapeake Bay Program (CBP). MODIS satellite data are then used to demonstrate how this tool can be used to describe sediment processes in the Northern Chesapeake Bay during a high rainfall event in June of 2006 and March 2008. In addition, we use MODIS Band 1 satellite data to study regional and seasonal TSM dynamics during 2009. This daily, high resolution, remotely sensed, near surface TSM concentration, in combination with other subsurface estimates of sediment transport (Fugate et al., 2007), can potentially support efforts to monitor sediment dynamics in the Chesapeake Bay.

\section{Methods}

\subsection{In situ sampling}

Routine and event driven sampling operations were conducted in the mid region of the Chesapeake Bay from April 2006 to December 2008 to support satellite ocean color validation and algorithm development activities. Sampling efforts have been designed to be portable and "ready to deploy" so as to allow rapid response sampling when ephemeral events of interest occur or in the event of clear sky conditions for routine sampling. Many episodic blooms and runoff events last only a day or two and sampling is opportunistic and can be difficult to coordinate. Rapid deployment is often necessary to sample an event of interest under conditions that allow satellite and in situ measurement matchups. All sampling efforts in this study were conducted aboard the NOAA vessel, the R/V Alosid, a $21 \mathrm{ft}$. Parker based at the Smithsonian Environmental Research Center (SERC). The central location enabled sampling several locations each day in the mid-Chesapeake Bay within a few hours of satellite overpasses. Stations occupied during 2006, 2007 and 2008 are mapped in Fig. 1. Event driven sampling takes place when a stress indicator of interest is identified. These are identified by word of mouth from local watermen and sport fishermen, newspaper articles, agency notifications (DNR and Environmental Protection Agency (EPA)), and monitoring satellite near real-time imagery. Routine sampling took place during clear sky conditions with typical sampling intervals of twice a month and no longer interval than once quarterly during the 3 year period from 2006 to 2008 .

\subsection{Characterization of runoff events}

Throughout our sampling period, daily true color imagery was used to identify events of interest and guide our sampling. For example, during June 2006, there was a large precipitation event in the Chesapeake watershed. Much of the watershed received up to 8 inches of rain and some isolated regions in the Bush, Potomac, Susquehanna and mid-Eastern Shore watersheds received 12-16 in. of rain. This event was preceded by dry periods with March 2006 being one of the driest March's ever recorded. This dry spell, being followed by above average rains, resulted in a large sudden release of water from the Susquehanna River and runoff into the bay. TSM load is known to vary with river flow (Ko \& Baker, 2004) and this can be seen in true color imagery where brownish water dominated the very northern section of the Chesapeake Bay (Fig. 2A). During the July 2006 and other runoff events, true color imagery enables sampling across runoff events to characterize the plume and survey a maximum concentration gradients.

Many of these events carry large sediment and CDOM loads. The high concentrations are revealed in true color imagery by the discoloration of the water in the northern Chesapeake. Observed during the 2006 runoff event were relationships between ocean color water leaving radiance spectra shape/magnitude and proximity to the northern/freshwater region of the Chesapeake Bay and TSM values. These relationships were explored throughout our 2006 and 2008 sampling and similar relationships were observed to remote sensing reflectance by Hu et al. (2004) and Miller and McKee (2004) where they observed increases in $n L_{w}$ (645) with increases in TSM concentrations.

\subsection{Measurements}

From the beginning of the project in 2006, our minimum in-situ routine sampling included optical measurements, extracted fluorometric chlorophyll a measurements (Chl), and total suspended matter (TSM) measurements.

\subsubsection{Optical measurements}

A Satlantic Profiler II (Hyperpro) equipped with Satlantic Hyperspectral Ocean Colour Radiometers (HyperOCR) was used to collect in-situ optical data (specifications and manuals for the Hyperpro can be found at http://www.satlantic.com). The profiler is equipped with a downward directed radiance HyperOCR to measure $L_{u}(\lambda)$ $\left(\mu \mathrm{W} / \mathrm{cm}^{2} / \mathrm{nm} / \mathrm{sr}\right.$ ) and an upward directed irradiance HyperOCR to measure $E_{d}(\lambda)\left(\mu \mathrm{W} / \mathrm{cm}^{2} / \mathrm{nm}\right)$. A third irradiance HyperOCR is used to measure reference $E_{s}(\lambda)\left(\mu \mathrm{W} / \mathrm{cm}^{2} / \mathrm{nm}\right)$ and is mounted on a gimbal 


\section{Hyperspectral/TSM/Chlorophyll Stations}

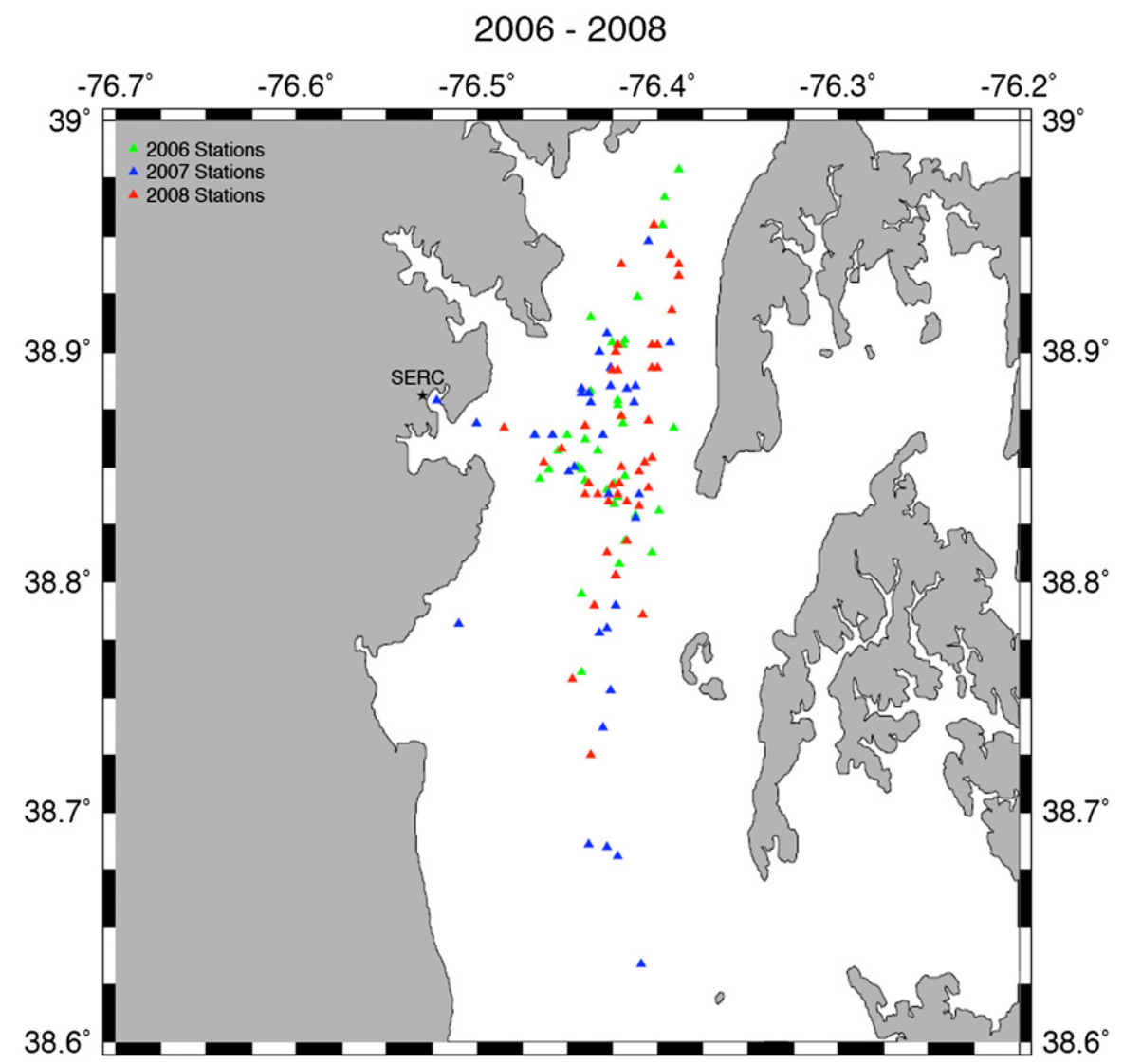

Fig. 1. Chesapeake Bay station locations collected during 2006 (green), 2007 (blue) and 2008 (red).

at the top of the vessel to both maintain nadir viewing and to avoid ship shadow.

The profiler was operated in a free falling profiling mode to avoid ship shadowing errors. In addition to the radiometers, the instrument package is equipped with tilt, temperature, depth, and two Wetlabs Ecopuc sensors. One Ecopuc sensor provides fluorometricallydetermined estimates of $\mathrm{Chl}\left(\mathrm{mg} / \mathrm{m}^{3}\right)$, CDOM ( $\left.\mathrm{ppb}\right)$ and phycoerythin (ppb). A second Ecopuc is a backscattering $\left(\mathrm{m}^{-1}\right)$ sensor measuring at 443,550 , and $860 \mathrm{~nm}$. The profiler descent rate is adjusted through small buoyancy changes and was set between $0.2 \mathrm{~m} / \mathrm{s}$ and $0.4 \mathrm{~m} / \mathrm{s}$ to increase the number of scans in the shallow euphotic zone found in these turbid waters.

The HyperOCRs have 136 channels calibrated within a range of 350 to $900 \mathrm{~nm}$. Each channel has a $3 \mathrm{~nm}$ spectral resolution and a $10 \mathrm{~nm}$ bandwidth. At each station, 4 to 5 replicate casts were taken in order to check repeatability and establish a reasonable mean value for the station. Each cast consists of a profile to below the euphotic zone where the amount of up-welled radiance and down-welled irradiance is near zero.

TSM and water leaving radiance measurements were made from 2006 to 2008 (Fig. 1). Working with Satlantic engineers in the beginning of 2008, we identified improvements in our Hyperpro measurement techniques and therefore excluded radiance data collected during early cruises (2006-2007) in our algorithm development. These improvements involved adding floatation to the profiler to slow the descent rate and resetting the starting gain settings for the OCR sensors. The slower descent rate increased the number of scans in the near surface waters which is critical in the often turbulent Chesapeake Bay waters where the upper optical depth can be as shallow as a few meters. Resetting the initial gain setting to a mid range value allows quicker instrument gain transition between dark, deeper measurements and bright surface measurements. On many of the 2006 and 2007 stations only the first profile collected acceptable data because the auto gain adjustment could not occur before the subsequent cast, resulting in saturated measurements during the subsequent casts. Implementation of these improvements increased the number and precision of replicate casts, resulting in better regression fits.

\subsubsection{Optical measurement data processing}

The HyperOCR optical data are processed using Satlantic Prosoft software version 7.7.9. Prosoft processes the HyperOCR data in four levels from level 1 to level 4 . Level 1 is the raw data collected from the instrumentation. Processing from level 1 to level 2, the raw data are calibrated using the latest calibration files supplied by Satlantic. In processing the data from level 2 to level 3, the data are dark corrected, high tilt values are excluded and the data are interpolated into either depth for the profiler or time for the $E_{s}$ reference. The HyperOCRs are dark corrected using shutter dark measurements collected every 5th scan. When the data processes from Level 3 to level 4, the data are averaged by time and depth, as defined in the processing set up. Level 4 processing includes higher level products such as normalized water leaving radiance and remote sensing reflectance.

Normalized water leaving radiance $\left(n L_{w}(\lambda)\right)$ is calculated using the equation:

$n L_{w}(\lambda)=L_{w}(\lambda) *\left[F_{o}(\lambda) / E_{s}(\lambda)\right]$

where $F_{o}$ is the mean extraterrestrial solar irradiance (Neckel and Labs, 1984) and $E_{s}(\lambda)$ is the downwelling spectral irradiance just above the surface and is measured directly with the above water 
HyperOCR irradiance collector. $L_{w}$ is the water leaving radiance calculated just above the surface:

$L_{w}\left(0^{+}, \lambda\right)=L_{u}\left(0^{-}, \lambda\right) *\left[(1-\rho(\lambda, \theta)) / n_{w}^{2}(\lambda)\right]$

Here, $\rho(\lambda, \theta)$ is the Fresnel reflectance index of seawater and is set as $0.021 . n_{w}(\lambda)$ is the Fresnel refractive index of seawater and is set here as $1.345 . L_{u}\left(0^{-}, \lambda\right)$ is the calculated upwelled radiance just below the surface and is determined by using the diffuse attenuation coefficient $\left(K_{l u}\right)$ calculated using a least squares regression fit from log transformed measured $L_{u}(\lambda)$ values and the intercept just below the surface.

The calculated hyperspectral normalized water leaving radiance values for each cast are compared for each station, outlier casts are removed and the casts are averaged. Outliers were saturated cast or those that were identified visually to not match all the other cast in the station. If at least 3 profiles did not match, the station was discarded. The station averaged normalized water leaving radiance values are then spectrally weighted to match the MODIS Aqua spectral response functions (http://oceancolor.gsfc.nasa.gov/DOCS/RSR_tables.html).

\subsubsection{Total suspended matter}

One to three TSM samples were collected for each station. One liter of water was collected for each sample and kept at ambient temperatures until it could be filtered onshore. TSM was measured using the techniques outlined in Hunter, 2006. The Bay water was filtered on pre-weighed $47 \mathrm{~mm}$ diameter, $0.45 \mu \mathrm{m}$ Millipore ${ }^{\mathrm{TM}}$ nitrocellulose filter. The samples were filtered under positive pressure until the filtration stopped. The volume of the filtrate was then measured with a graduated cylinder and recorded. The filters are placed in $47 \mathrm{~mm}$ diameter Petri dishes and oven dried at $60^{\circ} \mathrm{C}$ for $12 \mathrm{~h}$ then stored in a desiccator until analysis. The filters were weighed on a Mettler ${ }^{\mathrm{TM}}$ H54AR balance (with and accuracy of $0.01 \mu \mathrm{g}$ ) and weighed repeatedly until a constant weight is determined.

\subsubsection{Chlorophyll a}

Chlorophyll concentrations were measured using a Turner $10 \mathrm{AU}$ Fluorometer. Surface samples were collected by hand and filtered on a $25 \mathrm{~mm}$ GFF filter. The filters were extracted in $90 \%$ acetone for at least $48 \mathrm{~h}$ then measured on the Turner $10 \mathrm{AU}$ before and after acidification.

\subsection{Satellite processing}

All satellite processing was done utilizing either the NASA SeaDAS processing utility (http://seadas.gsfc.nasa.gov/) or the NOAA CoastWatch
Utilities package (http://coastwatch.noaa.gov/cwn/cw_software.html). The default atmospheric correction for SeaDAS and CoastWatch utilizes the Near Infra-Red (NIR) technique (Gordon \& Wang, 1994; Stumpf et al., 2003). The atmospheric correction is based on the measured radiances at the two NIR wavelengths with the assumption that the water leaving radiances are negligible. In turbid waters, with high reflectance, this assumption can be wrong. Wang and Shi (2005) introduced a short-wave near-infrared (SWIR) atmospheric correction technique, utilizing the stronger absorption of SWIR bands in turbid waters, to improve coastal ocean color processing. To test the utility in this technique we processed imagery corresponding to our in situ TSM sampling during 2007 and 2008 using SeaDAS Version 6.1 with the NIR and with the NIR-SWIR atmospheric correction method of Wang and Shi (2007), Wang et al. (2009). For the NIR method, SeaDAS aerosol mode option -3 was selected which utilizes multi-scattering with 2-band model selection and the iterative NIR correction (Stumpf et al., 2003). The maximum number if iterations were set at the default value of 10. For the NIR-SWIR method, the SeaDAS aerosol mode option -9 was selected which utilizes multi-scattering with 2-band aerosol model selection. Switching of the SWIR or NIR method is based on the criteria of Wang et al. (2009).

Unlike for developing the algorithm in which SeaDAS was used, for validating the TSM algorithm, the CoastWatch Utilities were used on 2009 data. The only difference between the CoastWatch Utilities processing and the NASA SeaDAS processing utility is that CoastWatch utilizes near real-time ancillary data, and therefore we expect negligible differences between the two systems (Ramachandran \& Wang, 2011). Changing processing techniques was necessitated due to different data sources (NASA and NOAA). From 2006 to 2008, NASA generated data used to validate the algorithm had to be processed using SeaDAS. From January 1, 2009 to present, daily TSM concentrations for the Chesapeake Bay were processed and stored at NOAA CoastWatch using CoastWatch Utilities during the validation process.

During the 2006 to 2008 sampling period, discrepancies were observed when the $250 \mathrm{~m}$ true color imagery, used to monitor sediment runoffs and to guide our sampling efforts, was compared to $n L_{w}$ (645) values (Fig. 2, circled regions). When high sediment waters in the very northern section of the Chesapeake Bay were identified by clear true color imagery (Fig. 2A), corresponding $n L_{w}$ (645) values were consistently masked out (Fig. 2B). In both the SeaDAS and CoastWatch Utilities processing, a high light flag (maskhilt) is ordinarily used to mask high reflections that changed the satellite detector gain setting, which can be triggered by sediments in high runoff regions. It was determined that this high light flag (maskhilt) was masking the data. When using these high light masked pixels, there is an expected loss of precision, yet no discontinuity in the transition from nonmasked to masked regions were observed so the data are considered
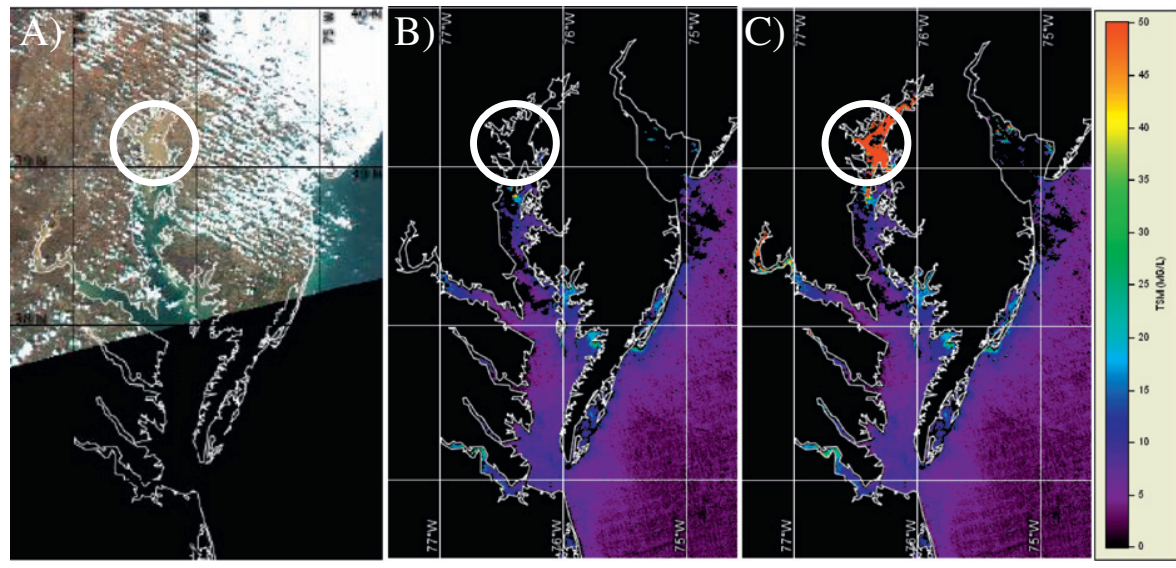

Fig. 2. True color imagery (A) along with $n L w$ (645) processed with (B) and without (C) HILT mask. (Data courtesy of NASA/GSFC MODIS processed by NOAA CoastWatch). 


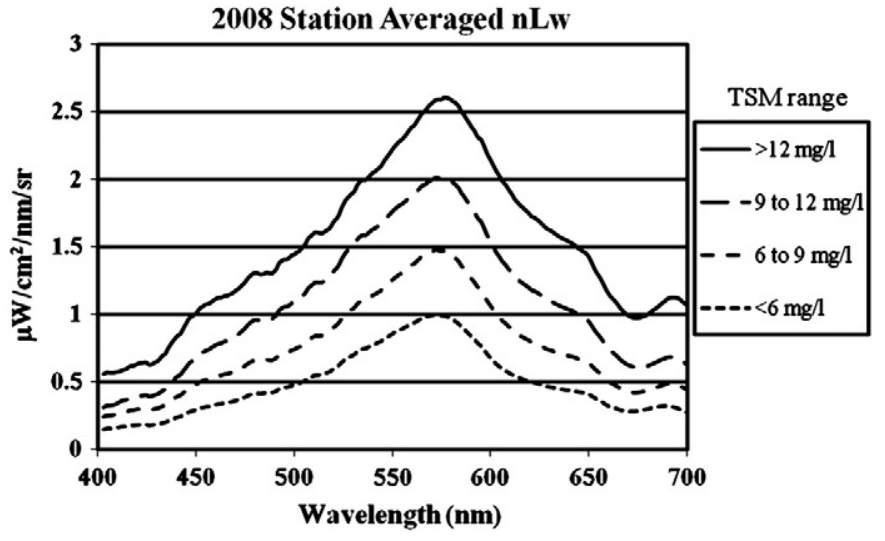

Fig. 3. Concentration range averaged in situ measured Hyperpro spectral water-leaving radiances for Stations sampled in 2008.

to be reasonable. Therefore, this loss of precision is deemed acceptable when monitoring extreme range runoff values that would otherwise be missed. By disabling the flag, we allow high sediment loads to be displayed (Fig. 2C) providing better monitoring of runoff events and temporal patterns of sediment distributions in the Chesapeake Bay.

\section{Results}

Generally, throughout the study period, higher water-leaving radiances were associated with higher TSM concentrations. Range binned, station averaged spectral data for 2008 is shown in Fig. 3. The spectral shape does not change dramatically but the magnitude does. The $n L_{w}$ spectral peak ranges from 575 to about $580 \mathrm{~nm}$ with a secondary peak located near $690 \mathrm{~nm}$. The 575 to $580 \mathrm{~nm}$ peak ranged in value from 0.64 to $3.41 \mu \mathrm{W} / \mathrm{cm}^{2} / \mathrm{nm} / \mathrm{sr}$. When the spectral $n L_{w} s$ (Fig. 3) are spectrally weighted to the MODIS band 1 spectra response, we get a range of satellite band weighted $n L_{w}$ (645) values. The $n L_{w}$ (645) values ranged from 0.301 to $2.157 \mu \mathrm{W} / \mathrm{m}^{2} / \mathrm{nm} / \mathrm{sr}$. The data calculated for 2008 is presented in Table 1 . These data are valuable for algorithm development, product algorithm validation, and direct satellite measurement validation.

To develop a high resolution TSM product for the Chesapeake Bay, 2008 in situ measured $n L_{w}$ data, spectrally weighted to MODIS Band 1 $(645 \mathrm{~nm})$, is plotted against measured TSM data in Fig. 4. This data includes all the 2008 collected data in Table 1 except two stations with high TSM concentrations greater than $35 \mathrm{mg} / \mathrm{l}$. In these turbid waters, instrument shading and the rapid attenuation of light resulted in in-water $n L_{w}$ measurements that were inconsistent and had too few high-quality replicates to use in the algorithm.

Two relationships were explored for predicting TSM concentrations from MODIS Band 1 values. Fig. 4A utilizes a linear regression to relate in situ measured TSM concentrations to in situ measured $n L_{w}$ (645) spectrally weighted to MODIS band 1 . This method follows the model of Miller and McKee (2004) except they utilized a linear regression to relate satellite measured remote sensing reflectance $\left(R_{r s}(645)\right)$ to in situ measured TSM. In Fig. 4B the data are fit using a 3rd order polynomial with the $y$-intercept forced through zero. The 3rd order Polynomial fit in $4 \mathrm{~B}$ used in subsequent processing and application of the TSM product uses the following equation:

$$
\begin{aligned}
\operatorname{TSM}(\mathrm{mg} / \mathrm{l})= & 3.8813\left(n L_{w}(645)\right)^{3}-13.822\left(n L_{w}(645)\right)^{2} \\
& +19.61\left(n L_{w}(645)\right)
\end{aligned}
$$

The linear fit in Fig. 4A has an $\mathrm{r}^{2}$ of 0.828 and the intercept crosses the $y$ axis at $4.1 \mathrm{mg} / \mathrm{l}$. The $\mathrm{r}^{2}$ for this polynomial fit is 0.79 .
Table 1

$2008 n L w$, TSM and Chl station data. nLw (645) is spectrally weighted to match the MODIS Aqua Spectral Response with units of $\mu \mathrm{W} / \mathrm{cm}^{2} / \mathrm{nm} / \mathrm{sr}$. TSM is in $\mathrm{mg} / \mathrm{l}$, Chl is in $\mathrm{mg} / \mathrm{m}^{3}$, Latitude (Lat) is in degrees north, Longitude (Lon) is in degrees west and wavelengths are in $\mathrm{nm}$. Based on replicate measurements, the average measurement uncertainty (standard deviation/square root of $\mathrm{N}$ ) for the ranges shown are $0.52 \mathrm{mg} / \mathrm{m}^{3}$ for

\begin{tabular}{|c|c|c|c|c|c|c|c|}
\hline Mo. & Day & Sta\# & Lat & Lon & nLw (645) & TSM & Chl \\
\hline Jan & 4 & 1 & 38.84 & 76.42 & 1.14 & 11.37 & 30.09 \\
\hline Jan & 4 & 3 & 38.87 & 76.44 & 0.94 & 9.42 & 27.22 \\
\hline Mar & 6 & 1 & 38.72 & 76.44 & 0.48 & 8.55 & 15.76 \\
\hline Mar & 6 & 2 & 38.83 & 76.41 & 0.77 & 8.37 & 14.38 \\
\hline Mar & 6 & 3 & 38.94 & 76.39 & 0.82 & 6.65 & 6.27 \\
\hline Mar & 6 & 4 & 38.94 & 76.42 & 0.83 & 8.74 & 11.31 \\
\hline Mar & 6 & 5 & 38.87 & 76.48 & 1.16 & 11.57 & 14.16 \\
\hline Mar & 11 & 1 & 38.95 & 76.40 & $4.00^{\mathrm{a}}$ & $55.29^{a}$ & 30.08 \\
\hline Mar & 11 & 2 & 38.94 & 76.39 & $2.55^{\mathrm{a}}$ & $38.00^{\mathrm{a}}$ & 67.85 \\
\hline Mar & 11 & 4 & 38.90 & 76.42 & 2.03 & 14.92 & 21.66 \\
\hline Apr & 16 & 1 & 38.79 & 76.41 & 0.98 & 9.04 & 11.13 \\
\hline Apr & 16 & 2 & 38.84 & 76.40 & 1.41 & 12.36 & 6.00 \\
\hline Apr & 16 & 3 & 38.85 & 76.40 & 1.31 & 9.26 & 9.34 \\
\hline Apr & 16 & 4 & 38.92 & 76.39 & 1.37 & 8.36 & 10.39 \\
\hline Apr & 16 & 5 & 38.89 & 76.42 & 1.20 & 9.66 & 9.58 \\
\hline Apr & 16 & 6 & 38.86 & 76.45 & 1.13 & 9.59 & 16.09 \\
\hline May & 5 & 1 & 38.83 & 76.42 & 0.61 & 6.82 & 15.98 \\
\hline May & 5 & 2 & 38.87 & 76.40 & 0.71 & 6.85 & 35.10 \\
\hline May & 5 & 3 & 38.90 & 76.40 & 0.60 & 6.95 & 11.52 \\
\hline May & 5 & 4 & 38.93 & 76.39 & 0.53 & 4.89 & 51.58 \\
\hline May & 13 & 1 & 38.84 & 76.42 & 1.22 & 10.75 & 14.28 \\
\hline May & 13 & 2 & 38.87 & 76.42 & 1.27 & 10.69 & 20.37 \\
\hline May & 29 & 1 & 38.79 & 76.44 & 0.45 & 4.50 & 5.54 \\
\hline May & 29 & 2 & 38.84 & 76.42 & 0.39 & 5.01 & 6.45 \\
\hline Jul & 3 & 1 & 38.82 & 76.42 & 0.36 & 5.61 & 15.16 \\
\hline Jul & 3 & 1 & 38.82 & 76.42 & 0.30 & 5.61 & 15.16 \\
\hline Jul & 3 & 2 & 38.85 & 76.41 & 0.34 & 6.57 & 18.98 \\
\hline Jul & 3 & 3 & 38.90 & 76.40 & 0.40 & 6.65 & 17.79 \\
\hline Jul & 3 & 3 & 38.90 & 76.40 & 0.49 & 6.65 & 17.79 \\
\hline Aug & 12 & 1 & 38.84 & 76.43 & 0.36 & 5.90 & 13.09 \\
\hline Sep & 3 & 2 & 38.83 & 76.43 & 0.44 & 7.77 & 17.25 \\
\hline Sep & 18 & 1 & 38.80 & 76.42 & 0.43 & 7.61 & \\
\hline Sep & 18 & 2 & 38.85 & 76.41 & 0.36 & 6.63 & \\
\hline Oct & 7 & 1 & 38.81 & 76.43 & 0.68 & 10.69 & 7.39 \\
\hline Oct & 7 & 2 & 38.85 & 76.42 & 0.39 & 9.27 & 12.93 \\
\hline Oct & 23 & 1 & 38.84 & 76.44 & 0.67 & 9.32 & 21.85 \\
\hline Oct & 23 & 2 & 38.85 & 76.46 & 1.47 & 12.14 & 25.31 \\
\hline
\end{tabular}
TSM, $0.79 \mathrm{mg} / \mathrm{m}^{3}$ for Chl, and $0.024 \mu \mathrm{W} / \mathrm{cm}^{2} / \mathrm{nm} / \mathrm{sr} n L_{w}(645)$.

a Processed using different parameterizations and excluded in subsequent algorithm development.

\section{Discussion}

\subsection{Algorithm comparison}

A comparison and validation of the two $n L_{w}$ (645)-TSM relationships from Fig. 4 and the Miller \& McKee (2004, Fig. 2) algorithm is given in Fig. 5. One difference seen in the algorithms is in the lower radiance-TSM ranges. The Miller and McKee (2004) algorithm has a negative $\mathrm{y}$-intercept of $-1.9 \mathrm{mg} / \mathrm{l}$, the linear algorithm from Fig. $4 \mathrm{~A}$ has a positive $y$-intercept of $4.15 \mathrm{mg} / \mathrm{l}$ and in the polynomial algorithm from Fig. 4B the y-intercept is forced through zero. Clear water MODIS Band $1 n L_{w}$ (645) is expected to be relatively close to zero $(0.02 \mu \mathrm{W} /$ $\mathrm{cm}^{2} / \mathrm{nm} / \mathrm{sr}$, Howard Gordon, personal communication) compared to values measured in the Chesapeake Bay, however, when using the linear regression in Fig. 4A, forcing the intercept through zero does not produce a significant relationship. For a validation of the lower end of the TSM spectrum, we considered oligotrophic data measured at the Marine Optical Buoy (MOBY) site $\left(20.49^{\circ} \mathrm{N}, 157.11^{\circ} \mathrm{W}\right)$. This site off the coast of Lanai, Hawaii, receives very little terrestrial input, and therefore has very low TSM concentrations. Concurrent TSM and MOBY radiances spectrally weighted to MODIS band 1 from 2002 were measured and plotted in Fig. 5 (circles). The band $1 n L_{w s}$ (645) measured by MOBY were 0.0195 and $0.0129 \mu \mathrm{W} / \mathrm{cm}^{2} / \mathrm{nm} / \mathrm{sr}$ for January 23, 2002 and May 27, 2002, respectively. The corresponding TSM values 
A

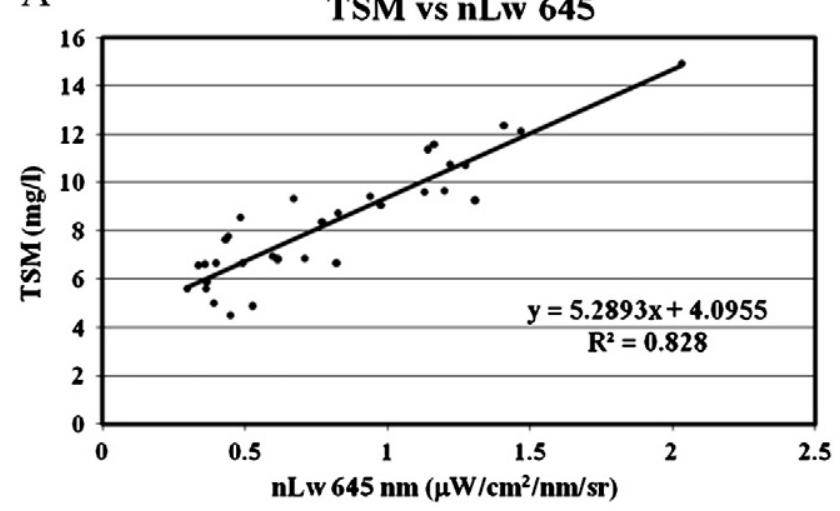

B

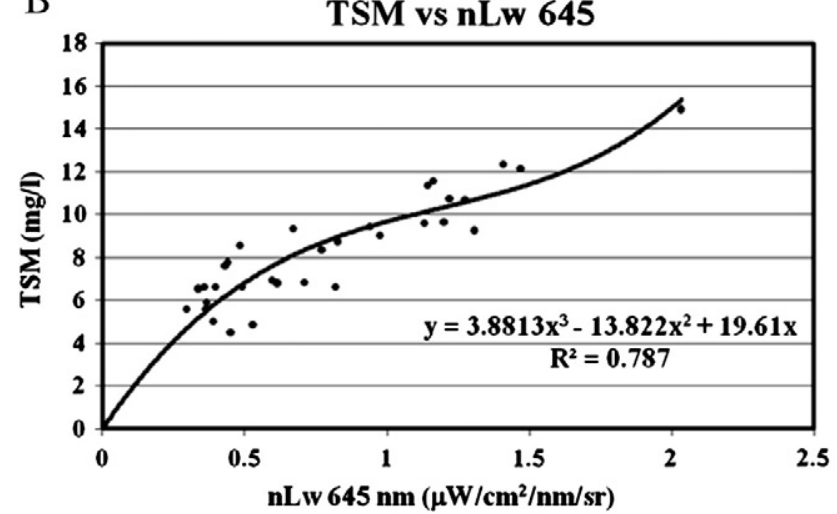

Fig. 4. Plots of 2008 TSM versus in situ measured $n L_{w}$ (645) corresponding to the high resolution MODIS band 1 . A) Predicts TSM using a linear regression fit through the data B) Same data plotted in A) except with a 3rd order polynomial fit to the data with the $\mathrm{y}$-intercept forced through zero.

measured during optical cruises were 0.107 and $0.10 \mathrm{mg} / \mathrm{l}$, respectively. These numbers fall relatively close to the polynomial regression $y$ intercept of zero, justifying the forced intercept.

The 2002, 2007 and 2008 in-situ measured TSM-radiance combination data pairs (Chesapeake Bay - squares; MOBY - circles) are compared to the linear, polynomial, and Miller and McKee (2004) algorithms in Fig. 5 (following conversion of their algorithm from $R_{r s}$ to $n L_{w}$ ). All three of these relationships are empirical and this could account for some of the observed differences since the Miller and Mckee (2004) in situ data was collected in Mississippi Delta region where regional differences in sediment types may exist. The Miller and McKee (2004) algorithm underestimates TSM at all concentration ranges. Some of this underestimation may also result from the different methods used by Miller and McKee (2004) in developing their algorithm. Their algorithm was developed using satellite measured $R_{r s}$ and in-situ measured TSM values. The use of satellite determined radiances in developing an algorithm ties the algorithm to satellite calibration and processing at the time and leads to the possibility that the relationship could be sensitive to changes in the satellite performance when applying this algorithm to other datasets. Contrasting and validating algorithms developed from satellite-based data can be difficult unless the satellite processing used is exactly the same. Miller and McKee (2004) utilized a different atmospheric correction than used in this study. They use a clear water technique of Gordon and Morel (1983). These differences make direct comparisons and utilization challenging.

When compared to in-situ measured radiance-TSM data pairs (Fig. 5) the linear algorithms (Miller and McKee (2004) and this study (Fig. 4A)) exhibit an underestimation of TSM in the higher radiance ranges (Fig. 5). During the large Chesapeake Bay runoff event in March 2008 (Fig. 2), the highest in-situ TSM concentration measured was $55 \mathrm{mg} / \mathrm{l}$ and

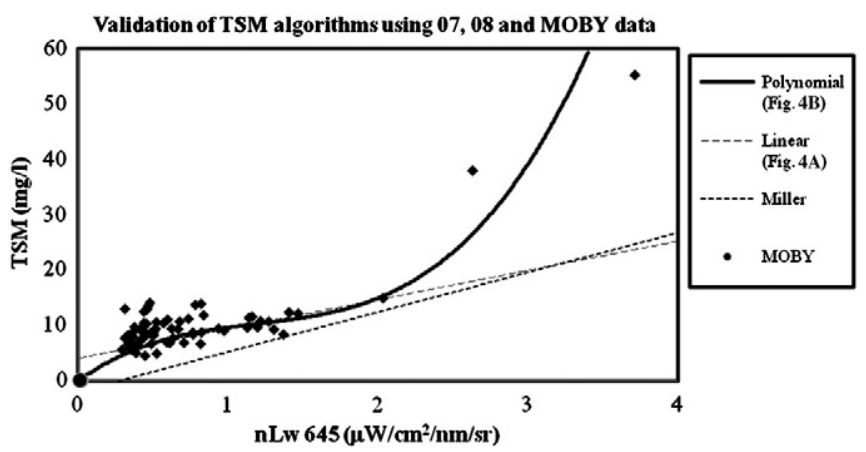

Fig. 5. Comparison of the linear (Fig. 4A), polynomial (Fig. 4B), and Miller algorithms overlaid with 2007 and 2008 in situ TSM versus in situ nLw (645) measurements from this study (diamonds) and with 2003 MOBY data (circles).

higher values were most likely present further north of the Chesapeake Bay Bridge where the plume originated. The highest $n L_{w}(645)$ values in the image ranged primarily between 3.5 and $4 \mu \mathrm{W} / \mathrm{cm}^{2} / \mathrm{nm} / \mathrm{sr}$ with the maximum value at $5 \mu \mathrm{W} / \mathrm{cm}^{2} / \mathrm{nm} / \mathrm{sr}$. Using Miller and McKee's (2004) algorithm a TSM of $55 \mathrm{mg} / \mathrm{l}$ would correspond to a $n L_{w}$ (645) value of about $8 \mu \mathrm{W} / \mathrm{cm}^{2} / \mathrm{nm} / \mathrm{sr}$ and our new linear algorithm (Fig. $4 \mathrm{~A}$ ) would coincide with a $n L_{w}(645)$ of $9 \mu \mathrm{W} / \mathrm{cm}^{2} / \mathrm{nm} / \mathrm{sr}$. The polynomial algorithm (Fig. 4B) at $55 \mathrm{mg} / \mathrm{l}$ matches to a $n L_{w}$ (645) of $3.3 \mu \mathrm{W} / \mathrm{cm}^{2} / \mathrm{nm} /$ sr which falls more in line with the range of values that is encountered in $n L_{w}$ (645) imagery and measured in situ data. Applying the regression to $n L_{w}$ (645) values higher than that used to develop the algorithm reduces the reliability in the data prediction. This uncertainty however, will decrease as further sampling can be achieved following high TSM runoff events in the future. In the interim, we accept higher uncertainties at elevated TSM concentrations for the purposes of this study.

Theoretically, at higher TSM concentrations the relationship between $n L_{w}$ (645) and TSM should not be linear. With higher particle concentrations, it is expected that the backscattering of light at $645 \mathrm{~nm}$ would begin to saturate due to the shading of particles. The polynomial relationship allows for the more rapid increase in the TSM: $n L_{w}$ (645) ratio at higher TSM concentrations. This deviation from the linear relationship was also observed by Petus et al. (2010) who utilized a second order polynomial regression and Rodríguez-Guzmán and Gilbes-Santaella (2009) who used an exponential algorithm to account for the change at higher concentration.

\subsection{Water-leaving radiance processing validation}

Chen et al. (2007) concluded in their analysis that the quality of the MODIS band 1 radiances ( $250 \mathrm{~m}$ resolution) is sufficient to use for ocean color applications. To test the utility of utilizing MODIS Band 1 data, we validated the NASA Ocean Biology Processing Group (OBPG) $n L_{w}$ (645) imagery by matching it with the Hyperpro in-situ measured $n L_{w}$ (645) data from 2007 to 2008. While it has been suggested that strict spatial temporal matchups are required during satellite matchup validation (Cui et al., 2010), we found, with higher resolution data $(250 \mathrm{~m})$, values determined by single pixel or by using $3 \times 3$ or $5 \times 5$ pixel averages made little difference in the determined validation data point (data not shown). Either single point or $3 \times 3$ average values are used in all subsequent analyses along with only clear pixels with no flags.

When processing with the default SeaDAS processing setting (NIR atmospheric correction), on average, the Hyperpro in situ measured water-leaving radiances were $22 \%$ higher than the Aqua measured radiances (Fig. 6, diamonds). Rodríguez-Guzmán and Gilbes-Santaella (2009) also observed that the standard SeaDAS 12gen processing produced lower water leaving radiances than in situ measured values. 
Wang and Shi (2005) suggested that the NIR method of determining aerosol optical depth in highly turbid waters can cause a significant underestimation of water-leaving radiances. When our 2007 and 2008 data were reprocessed using the NASA SeaDAS NIR-SWIR atmospheric correction method which is based on the Wang et al. (2009) technique, there is little difference between the NIR and the NIR/SWIR techniques. The Aqua radiances measured using the NIR-SWIR technique were 23\% lower than the Hyperpro measured radiances (Fig. 6, squares). The slope between the Hyperpro and satellite water leaving radiances for the NIR/SWIR method is 0.84 with an $r^{2}$ of 0.901 . The slope between the Hyperpro and satellite water leaving radiances for the NIR method is 0.78 with an $r^{2}$ of 0.896 . The RMSE compared to Hyperpro data is 0.397 for the NIR-SWIR and is 0.394 for the NIR method. Only pixels with no flags and which produced results for both techniques were used in the comparison. Of the 31 stations used in the comparison in Fig. 6 , only 8 stations had any pixels (out of 9 pixels in the $3 \times 3$ box) that exceeded the NIR-SWIR switching threshold and therefore were processed using SWIR bands (Wang et al., 2009). Out of these eight stations, only a total of 39 pixels switched to the SWIR processing. On average, the pixels processed with the SWIR atmospheric correction was $26 \%$ lower than when the same pixels were processed the NIR atmospheric correction. When just the switched (NIR and SWIR) pixels are used in the station averages and compared to the Hyperpro measurements (Fig. 7), the NIR atmospheric correction works better at low radiance levels while the SWIR processed pixels perform better at high radiance stations. This may partially explain the better slope but higher errors observed in the NIR-SWIR data compared to the NIR data in Fig. 6 since most of the station averaged $n L_{w}$ (645) values were less than $1 \mu \mathrm{W} / \mathrm{cm}^{2} / \mathrm{nm} / \mathrm{sr}$. Werdell et al., 2010 found that the low signal to noise ratio in the MODIS SWIR bands compared to the MODIS ocean-atmospheric-correction NIR band limited the utility of the NIR-SWIR atmospheric correction technique when processing Chesapeake Bay data. The low number of pixels identified in this study with good in-situ/satellite matches and that exceeded the NIR-SWIR atmospheric correction threshold $(n=39)$ did not allow for a conclusive evaluation of the NIR-SWIR method. Further work (and more data) will be needed to identify the more appropriate atmospheric correction.

\subsection{TSM algorithm validation}

For an independent evaluation with a wider range of values, we looked at 4626 total suspended solid (TSS) measurements collected by the Chesapeake Bay Program's Chesapeake Bay Water Quality Monitoring Program during 2009 (from here on referred to as TSM). The monitoring program samples 50 stations in Maryland and Virginia at once to twice a month intervals (Guide to Using the Chesapeake Bay Program Water Quality Monitoring Data, CBP/TRS 78/92, March

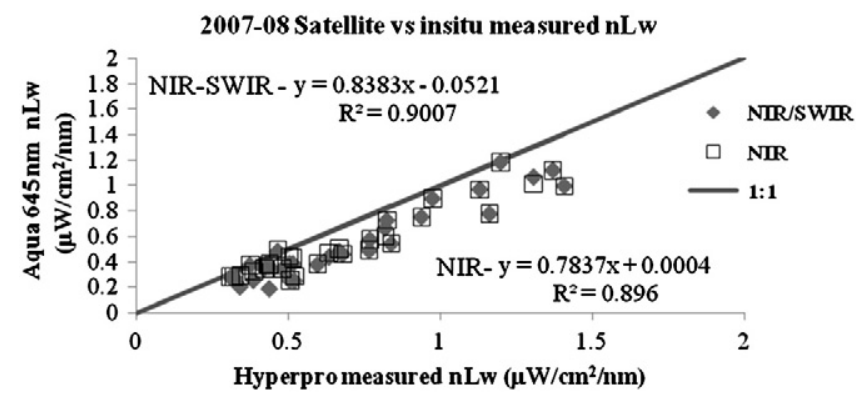

Fig. 6. Comparison of NIR versus NIR-SWIR atmospheric corrections. A. Plot displaying Hyperpro measured water-leaving radiances versus SeaDAS processed satellite data using the default NIR and optional NIR-SWIR atmospheric correction techniques at pixel binning resolutions of $3 \times 3$ averages. Line is 1:1 relationship. Only data points where both NIR and NIR-SWIR processing produced good data were used in comparison.
1993, http://archive.chesapeakebay.net/pubs/wquser.pdf). Water quality monitoring data in the top 1 meter in the Chesapeake Bay during 2009 were used for this validation. The TSM samples were collected and analyzed similar to our TSM analysis described above except that glass fiber filters were used instead of the nitrocellulose filters. Surface TSM values ranged from less than 1 to $3410 \mathrm{mg} / \mathrm{l}$ and of the 4626 potential surface matchups from 2009, 270 single satellite pixel matchups were retrieved. These were limited to cloud and flag free overpasses in the main stem of the Chesapeake Bay. The 270 matchups allow us a good analysis of the algorithm performance with a larger range of values than our initial data set (Fig. 5). The CBP TSM samples are plotted against the retrieved MODIS band 1 data in Fig. $8 \mathrm{~A}$ along with the polynomial algorithm (Fig. 4B). In situ versus satellite measured TSM values are plotted in Fig. 8B and reflect the negative bias observed in the MODIS radiances in Fig. 6. The polynomial algorithm reasonably predicts the TSM concentrations over a wide range of concentrations and seasons with a mean percent difference of $-4.2 \%$ and a mean absolute percent difference of $36 \%$. Although the development of the algorithm is based on mid-bay optical measurements, this validation implies the algorithm is applicable to whole bay.

\subsection{Chlorophyll effect on TSM}

To test if Chl concentrations might have an effect on the performance of the TSM algorithm or determined TSM concentrations, we plotted in situ measured Chl vs. in situ measured $n L_{w}$ (645) (Fig. 9A) and in situ measured TSM concentrations (Fig. 9B). No instantaneous relationship is evident in Fig. 9A between in situ measured $n L_{w}$ (645) which may suggest that Chl concentrations and bloom conditions will have little effect on TSM images determined using our TSM algorithm. While phytoplankton and CDOM absorption can have an effect on the spectral signature of $n L_{w}$ at wavelengths between $575 \mathrm{~nm}$ and $700 \mathrm{~nm}$ (Tzortziou et al., 2006), absorption at $645 \mathrm{~nm}$ is minimal and therefore processes influencing $n L_{w}$ (645) should be dominated by particle scattering with little absorption dependence on phytoplankton concentrations (Bricaud et al., 1995). However, we would expect higher nutrient concentrations to correlate with runoff volumes (Pan et al., 2010) and TSM concentrations, because nutrients can be eroded with sediments. It is also expected that chlorophyll concentration would succeed these events (Glibert et al., 2008; Roman et al., 2005). Sediments settle in a few days (Ruffin, 1998) allowing enough light to penetrate the water column and giving nutrient replete/light limited phytoplankton a chance to bloom. When TSM is plotted against Chl, a constant relationship was observed except during high Chl and high TSM events (Fig. 9B). The high TSM $(55 \mathrm{mg} / \mathrm{l})$ relatively low Chl $\left(30 \mathrm{mg} / \mathrm{m}^{3}\right)$ in the top of Fig. 9B was sampled north near Chesapeake Bay Bridge during the high sediment runoff event during March 2008. The high TSM

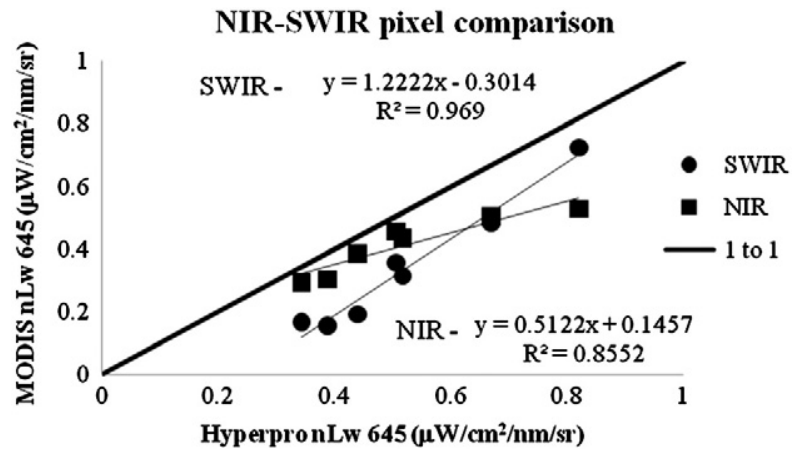

Fig. 7. Station averaged MODIS $n L w$ (645) radiances compared to Hyperpro measured nLw (645). Only pixels that exceeded the NIR-SWIR switching threshold were used in this plot. 
(38 $\mathrm{mg} / \mathrm{l})$ high $\mathrm{Chl}\left(68 \mathrm{mg} / \mathrm{m}^{3}\right)$ point was sampled on the same day as the $55 \mathrm{mg} / \mathrm{l}$ station above but further south of the plume possibly reflecting a further evolution point of the runoff event. This suggests anecdotally that high chlorophyll events follow high flow/TSM events (Roman et al., 2001; Yeager et al., 2005). More research is needed to confirm that such events are temporally related. TSM imagery, along with concurrent Chl imagery, can potentially be a useful tool in monitoring the runoff/bloom evolution, succession and timing on a routine basis in the Chesapeake Bay.

\subsection{Application of the algorithm}

\subsubsection{8 runoff event}

The TSM algorithm in Eq. (3) is used to demonstrate the utility of using TSM satellite imagery to track sediment plumes by monitoring the evolution of a runoff event in March 2008 following a significant Chesapeake Bay watershed rain event. In the March 6 image (Fig. 10A), following a large rain event, the sediment plume is just entering the northern section of the Bay. By March 9 (Fig. 10B), the plume extends most of the way to the Chesapeake Bay Bridge and sediment concentrations over $50 \mathrm{mg} / \mathrm{l}$ were observed. On March 10th (Fig. 10C) and March 11th (not shown) clouds obscured the northern bay where the sediment plume was located. Observed sediment concentrations peak around March 12 (Fig. 10D) and then dissipate slowly through March 13th, 14th, and 15th as observed by the retreat of the $>50 \mathrm{mg} / \mathrm{l}$ contour line (red) in Fig. 10E, F, and G. This progression and recession of the front results because suspended sediments tend to settle out of the water column over time with finer grain size sediments remaining suspended longer than larger particles (Ruffin, 1998). Elevated TSM concentrations were still observed on April 19th, north of the Chesapeake Bay bridge,

\section{A Satellite nLw vs CBPin situ TSM}
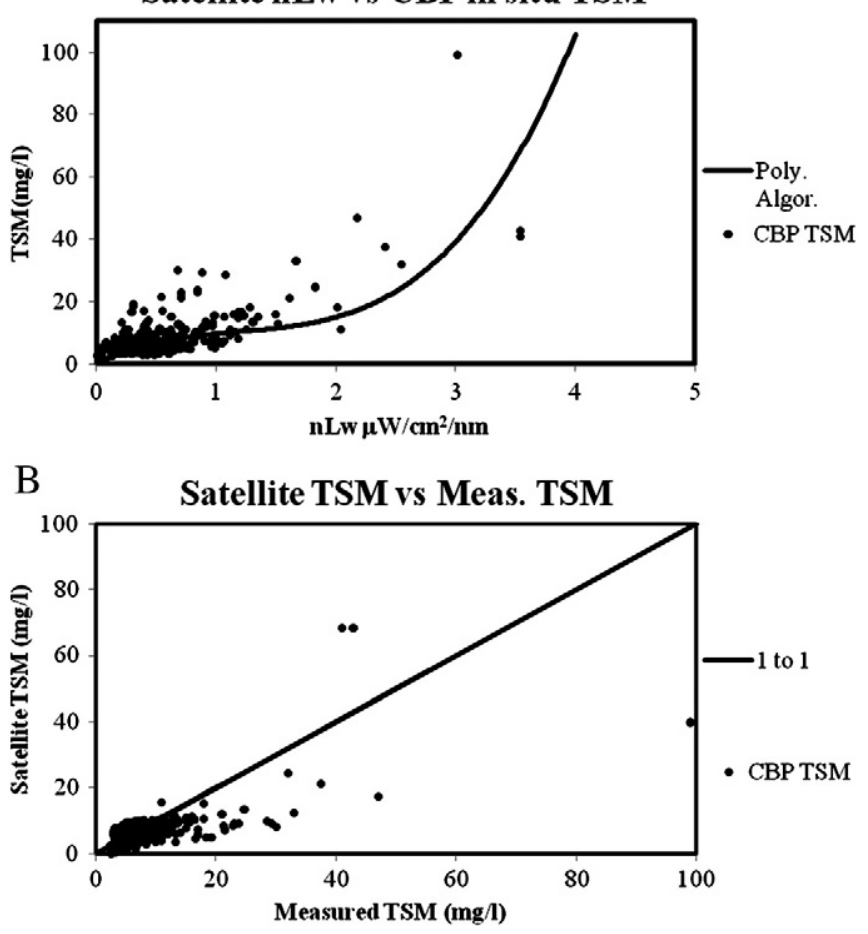

Fig. 8. Validation of the TSM algorithm. A). $3 \times 3$ pixel ( $250 \mathrm{~m}$ resolution) averaged satellite measured normalized water-leaving radiance (NIR-SWIR method) versus all near-surface in situ measured TSM values collected in 2009 from the Chesapeake Bay Program (CBP). Curve is the polynomial TSM algorithm from Fig. 4B. B). Satellite measured normalized water-leaving radiance (NIR-SWIR method, $1 \times 1$ pixel matchups) versus in situ measured TSM values.
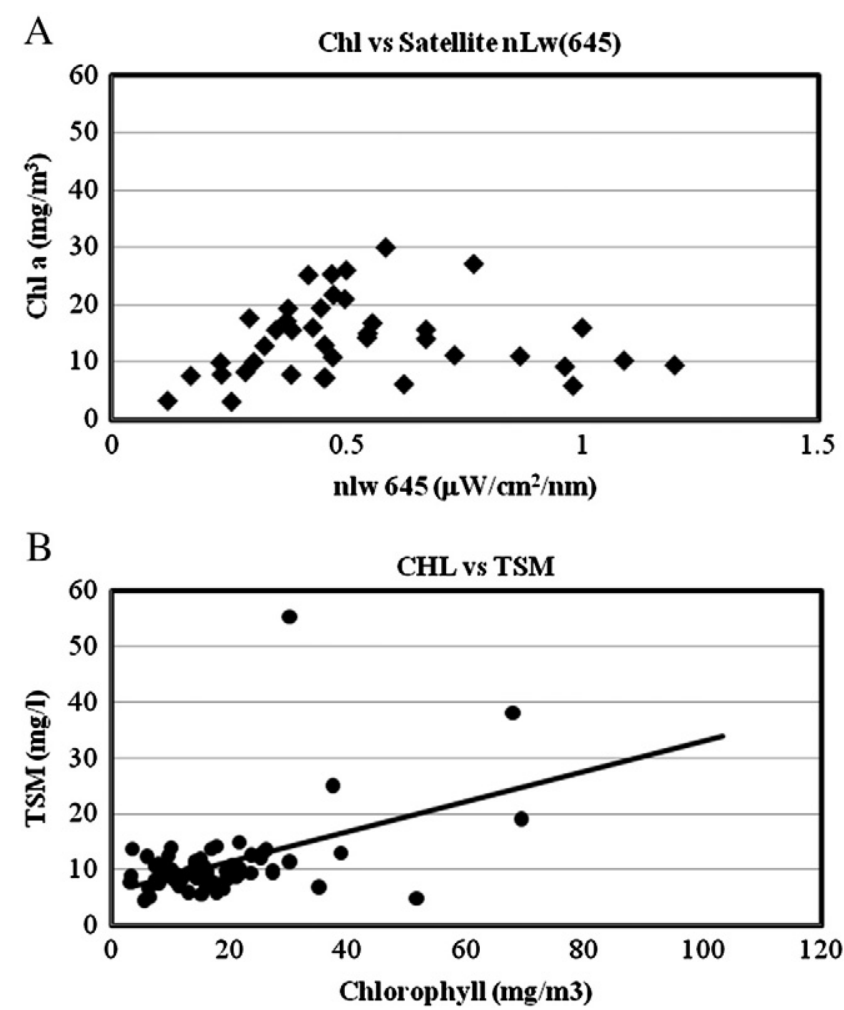

Fig. 9. In situ measured Chl from 2007 and 2008. A). In situ measured MODIS Aqua band $1(645 \mathrm{~nm})$ versus in situ measured Chl for data collected in 2007 and 2008 B). 2007 and 2008 in situ measured chlorophyll versus in situ TSM concentrations. The line is a least squares linear regression fit to the data.

(data not shown) and returned to conditions prior to the runoff event sometime between April 19 and May 2, as evidenced in the May 2 image in Fig. 10H. This demonstrates the effectiveness of using the TSM imagery in monitoring the evolution of runoff events and quantifying the daily surface sediment concentration as a result of these events.

\subsubsection{Intra-annual sediment dynamics}

To demonstrate the utility of using this TSM tool to monitor intraannual sediment dynamics in the Chesapeake Bay, daily, monthly and seasonal data were derived for 2009 using the algorithm in Fig. 4B and Eq. (3). Daily images of TSM concentrations of the Chesapeake Bay were run using NOAA CoastWatch Utilities. As mentioned above the HILT flag had to be switched to off to include the highest sediment concentrations in the very northern section of the Bay. An artifact of turning off the HILT flag was that some high erroneous values, possibly associated with clouds, were encountered and biased temporal binned data. An upper limit of $200 \mathrm{mg} / \mathrm{l}$ for TSM was set and values greater than this were not averaged. In addition, 11 days with a large number of these high erroneous TSM values were removed from the 2009 series. In calculating regional daily means and regional seasonal statistics, regions with less than 300 good pixels were excluded from the calculation.

\subsubsection{Monthly images}

To analyze the temporal patterns in sediment dynamics the averaged monthly means for 2009 were plotted in Fig. 11. Unlike 2008 which had the huge runoff event in March (Fig. 10), 2009 was a relatively uneventful year as far as sediment dynamics is concerned. Down estuary sediment transport can be associated with either wind events or high river discharge (North et al., 2004). Langland and Cronin (2003) point out those dominant, high sediment runoff events typically only occur 

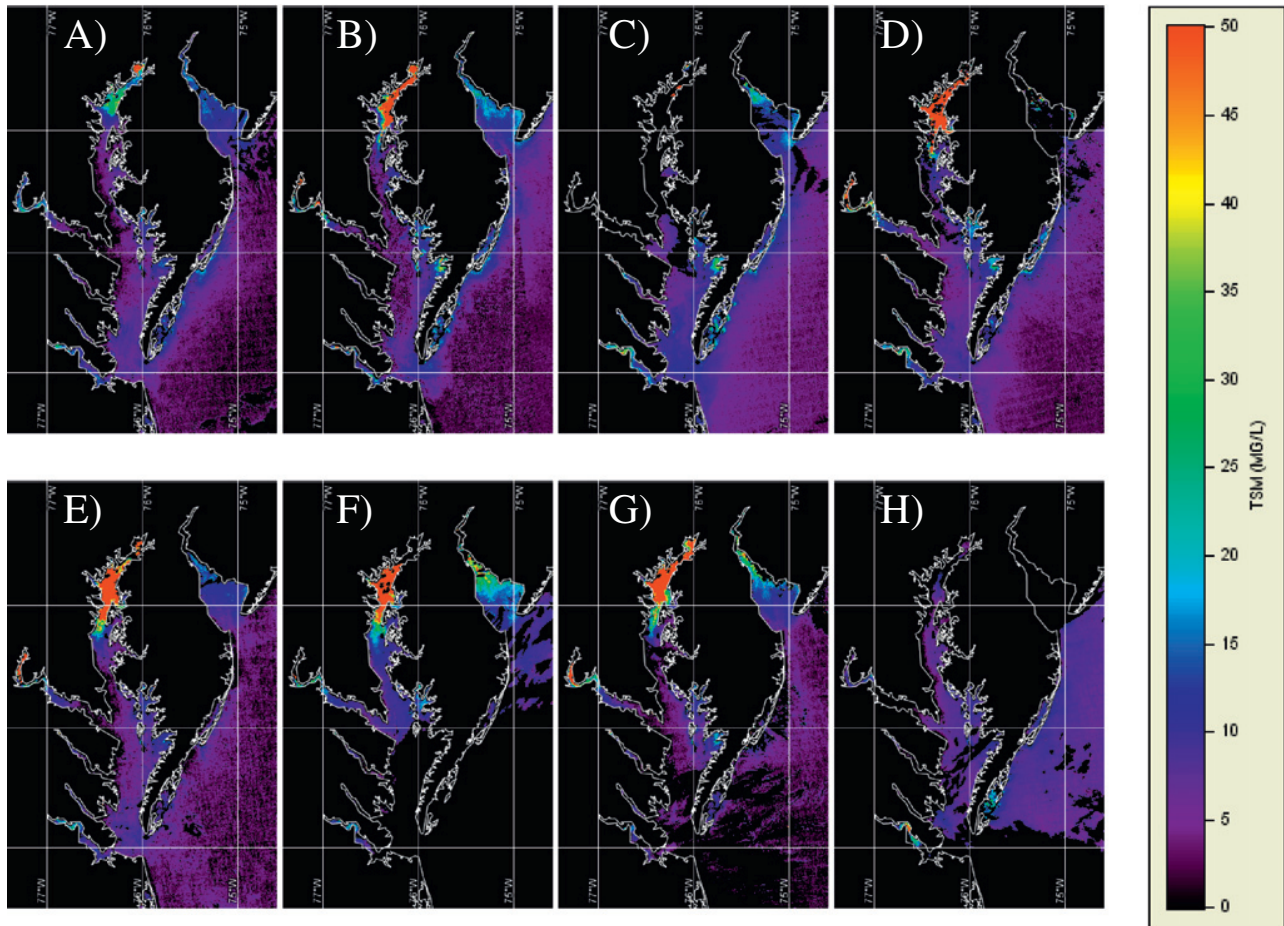

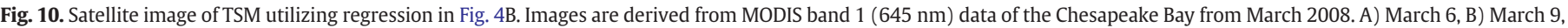
C) March 10, D) March 12, E) March 13, F) March 14, G) March 15, and H) May 2.

(Data courtesy of NASA/GSFC MODIS processed by NOAA CoastWatch).

every few years. Highest mean monthly concentrations for 2009 were observed during the winter months of November, December and January. All other months demonstrated consistent sediment distributions with little temporal variability. Very little seasonal variability is observed in the main stem mid-portion of the bay. Much of the eastern edge of the Middle bay is characterized by higher TSM concentrations than the main. These higher TSM concentrations most likely result from runoff from the eastern shore and the resuspension of sediments in shallow sections of the bay. Sediments are more easily disturbed in shallower waters where finer grain and silt particles likely dominate (Ruffin, 1998). There is also a possibility, that in cases of less turbid shallow waters, bottom reflectance may contribute to higher $n L_{w}$

\section{January February March April May June}

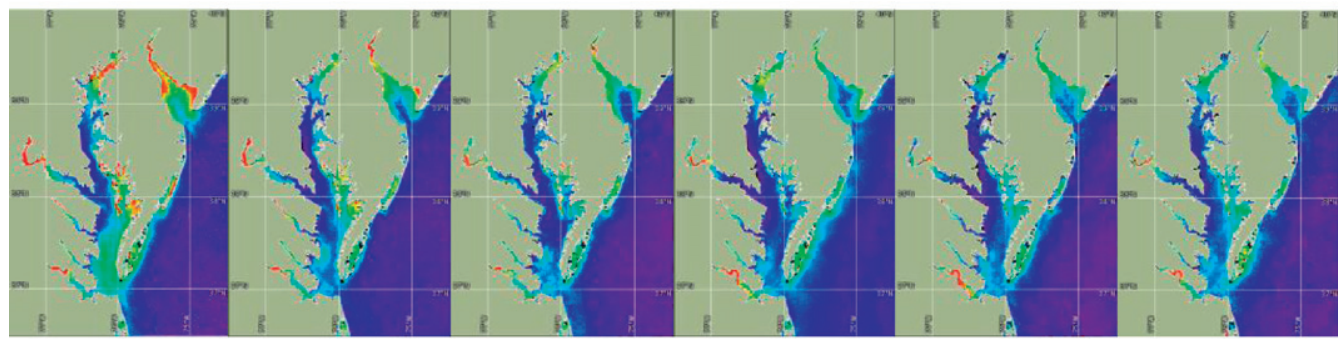

July August September October November December

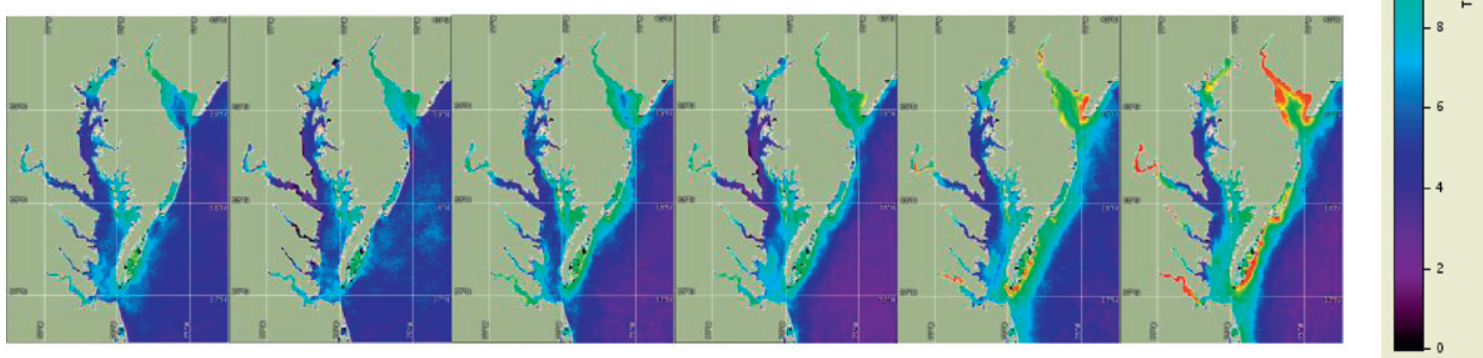

Fig. 11. Mean monthly TSM images for 2009 .

(Data courtesy of NASA/GSFC MODIS processed by NOAA CoastWatch). 
(645) fluxes. This needs to be explored but is beyond the scope of this paper.

\subsubsection{Regional daily means}

Fig. 11 demonstrated how the high resolution TSM algorithm can be used to monitor bay wide variability in sediment load. This TSM product can also be used to analyze sources and quantify region specific runoff sediment loads. To look at these relationships, we divided the bay into upper, middle and lower regions similar to Werdell et al. (2009, 2007) to study regional chlorophyll dynamics and originally defined by Magnuson et al. (2004) (Fig. 12). The only difference is that we included the most northern section of the Susquehanna flats. The upper region is defined as all bay waters north of $38.6^{\circ} \mathrm{N}$. The mid region is located between $37.6^{\circ} \mathrm{N}$ and $38.6^{\circ} \mathrm{N}$. This mid region includes the Tangiers Sound but excludes most of the Potomac River. The lower portion is defined as the main stem of the bay south of $37.6^{\circ} \mathrm{N}$. Fig. 13 displays the time series of daily mean by region. For the year 2009, for all three regions, day-to-day variability is smaller during the months April through October than the months November through March. Only one regional daily average exceeded $15 \mathrm{mg} / \mathrm{l}$ (Fig. 13). All three regions show highest TSM values in December and January with significant concentrations also found in February and March. The range of average values in Fig. 13 fall well within the range of TSM measurements observed by the CBP in Fig. 8 which averaged $9.4 \mathrm{mg} / \mathrm{l}$ for the entire year of 2009 .

\subsubsection{Seasonal averages of the regions}

The highest sediment concentrations are in the winter in the Upper and Middle Bay (Table 2), likely due to wintertime storm activity bringing sediments into the Chesapeake Bay (Langland \& Cronin, 2003). These high sediment concentrations drop off in the subsequent seasons. Interestingly, the Lower Bay exhibits higher sediment concentration than the Middle Bay during the spring, summer and autumn. It is

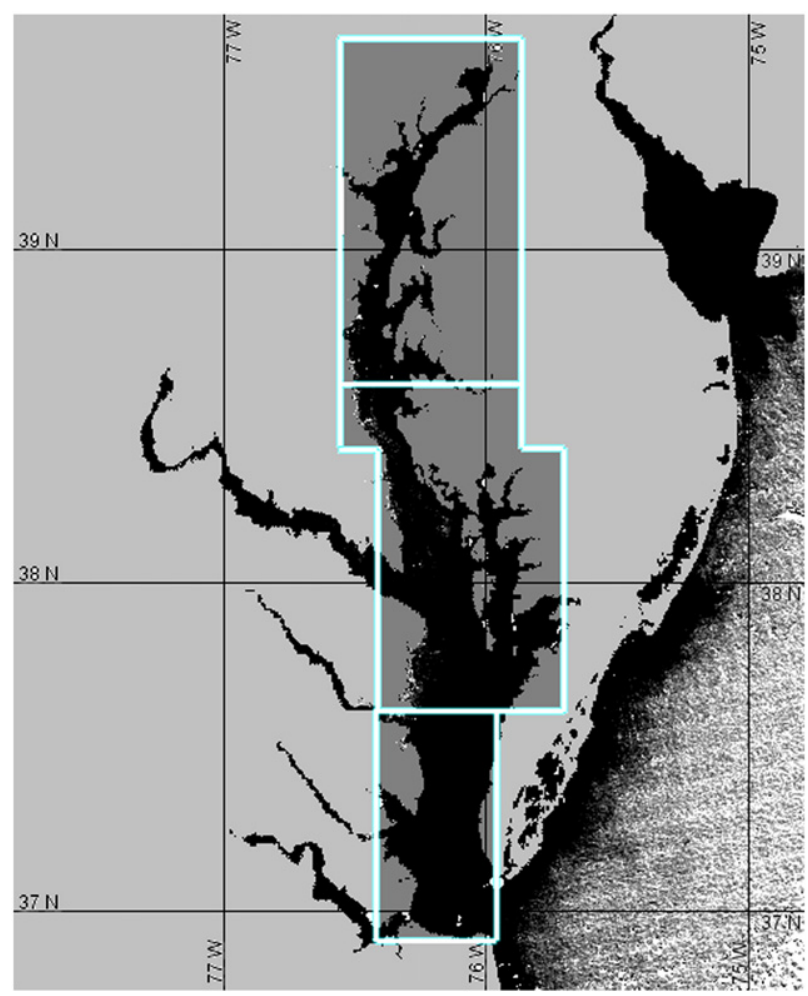

Fig. 12. Map of the Chesapeake Bay illustrating the boundaries used in the regional analysis.
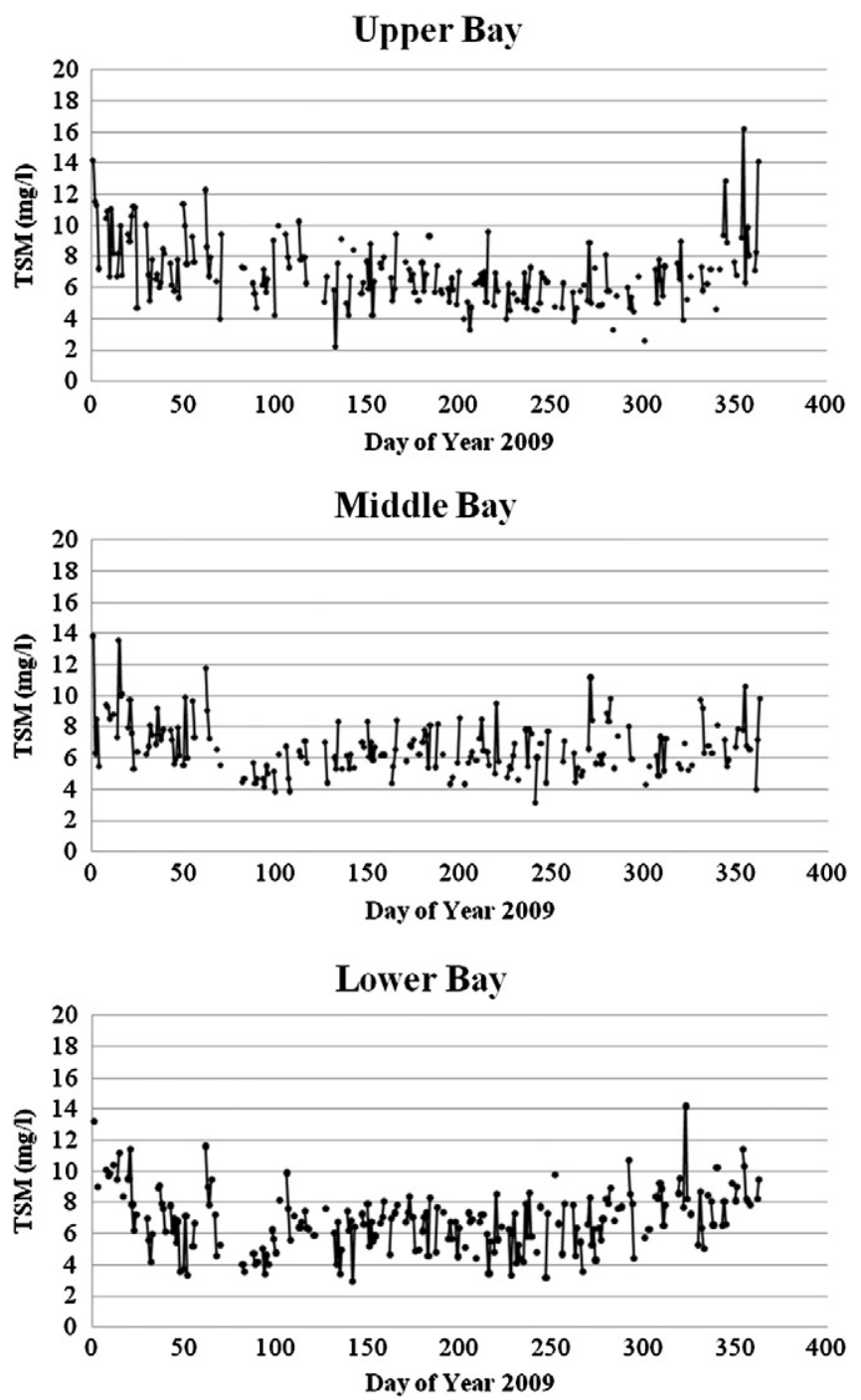

Fig. 13. Mean daily values of TSM for the upper, middle and lower sections of the bay corresponding to regions in Fig. 12.

possible that the sediment dynamics of the Lower Bay may be influenced by a sediment regime different from the Upper and Middle Bays. Whereas the Upper and Middle Bays have a sediment regime strongly influenced by the discharge from the Susquehanna and Potomac rivers, the Lower Bay may be more influenced by the James and York River discharges and greater tidal forcing due to proximity to the ocean.

\section{Summary}

Our goal is to develop quality, operational satellite imagery of the Chesapeake Bay that can be utilized in resource management decision making. We have developed a high resolution $(250 \mathrm{~m})$ algorithm for quantifying TSM in the Chesapeake Bay using MODIS Band 1 data. This algorithm will have to be validated in other regions before applying it to other localities. One of the primary reasons we expended the effort on the high resolution bands is that, in estuaries, use of these bands will allow more coverage in closer proximity to land. Using a $250 \mathrm{~m}$ pixel will improve the resolution of the processes relative to the spatial variability and allow measurements nearer to shore. We have validated this algorithm (mean percent difference of $-4.2 \%$ ) and demonstrated its utility in monitoring daily, monthly and seasonal sediment distribution patterns. Although the algorithm was developed 
Table 2

2009 Chesapeake Bay Seasonal Mean TSM (mg/l) by region. Seasons are Winter (Jan-Mar), Spring (Apr-Jun), Summer (Jul-Sep) and Fall (Oct-Dec).

\begin{tabular}{cllll}
\hline & Winter & Spring & Summer & Fall \\
\hline Upper Bay: & 11.55 & 7.37 & 6.38 & 7.18 \\
N: & 36,550 & 36,214 & 35,416 & 36,917 \\
Middle Bay: & 8.51 & 6.37 & 6.90 & 6.65 \\
N: & 76,025 & 74,914 & 74,616 & 75,630 \\
Lower Bay: & 7.53 & 7.03 & 7.19 & 7.86 \\
N: & 46,942 & 46,849 & 46,614 & 46,994 \\
\hline
\end{tabular}

with optical measurements in the mid-Chesapeake Bay and the use of the algorithm at high TSM concentrations outside of the range of measurements used to develop the algorithm, will result in decreased TSM accuracy, our validation shows applicability over the concentration ranges observed in 2009 for the entire Chesapeake (up to 100 mg/l TSM). This algorithm can potentially support Chesapeake Bay Program efforts in monitoring water quality. The next steps will be to use the surface TSM concentrations estimated with this tool and extrapolate this with depth to calculate the standing TSM concentration per pixel with depth. Monitoring these data over time will allow better quantification of total daily suspended solid concentrations in the Chesapeake Bay, and with assumptions of distribution within the water column, infer total maximum daily load for sediments.

\section{Acknowledgments}

We wish to thank the NOAA Chesapeake Bay Office for use of facilities and the $R / V$ Alosid. We wish to thank Michael Feinholz, Stephanie Flora, Dennis Clark, Carol Johnson, and Jeremy Werdell for valuable comments and advice. Support for this work was provided by NOAA Ocean Remote Sensing. The views, opinions, and findings contained in this paper are those of the authors and should not be construed as an official NOAA or US Government position, policy, or decision.

\section{References}

Bricaud, A., Babin, M., Morel, A., \& Claustre, H. (1995). Variability in the chlorophyllspecific absorption coefficients of natural phytoplankton: Analysis and parameterization. Journal of Geophysical Research, 100(7), 13321-13332.

Chen, T., Hu, C., \& Muller-Karger, F. (2007). Monitoring turbidity in Tampa Bay using MODIS/Aqua 250-m imagery. Remote Sensing of Environment, 109, 207-220.

Cui, T., Zhang, J., Groom, S., Sun, L., Smyth, T., \& Sathyendranath, S. (2010). Validation of MERIS ocean-color products in the Bohai Sea: A case study for turbid coastal waters. Remote Sensing of Environment, 114, 2326-2336.

Diaz, R. J., \& Rosenberg, R. (2008). Spreading dead zones and consequences for marine ecosystems. Science, 321, 926-929.

Doerffer, R., \& Schiller, H. (2007). The MERIS Case 2 water algorithm. International Journal of Remote Sensing, 28(3-4), 517-535.

Doxaran, D., Froidefond, J., Castaing, P., \& Babin, M. (2009). Dynamics of the turbidity maximum zone in a macrotidal estuary (the Gironde, France): Observations from field and MODIS satellite data. Estuarine, Coastal and Shelf Science, 81, 321-332.

Fugate, D. C., Friedrichs, C. T., \& Sanford, L. P. (2007). Lateral dynamics and associated transport of sediment in the upper reaches of a partially mixed estuary, Chesapeake Bay, USA. Continental Shelf Research, 27, 679-698.

Glibert, P. M., Kelly, V., Alexander, J., Codispoti, L. A., Boicourt, W. C., Trice, M., \& Michael, B. (2008). In situ nutrient monitoring: A tool for capturing nutrient variability and the antecedent conditions that support algal blooms. Harmful Algae, 8, 175-181.

Gordon, H. R., \& Morel, A. Y. (1983). Remote assessment of ocean color for interpretation of satellite visible imagery. A review. New York: Springer-Verlag 114

Gordon, H. R., \& Wang, M. (1994). Retrieval of water-leaving radiance and aerosol optical thickness over the oceans with SeaWiFS: A preliminary algorithm. Applied $O p$ tics, 33, 443-452.

Hu, C., Chen, Z., Clayton, T., Swarzenski, P., Brock, J., \& Muller-Karger, F. (2004). Assessment of estuarine water-quality indicators using MODIS medium-resolution bands: Initial results from Tampa Bay, FL. Remote Sensing of Environment, 93, 423-441.

Hunter, C. (2006). Particulate organic carbon, nitrogen and total suspended matter. Methodologies, protocols and analyses used in the development of ocean color product algorithms. Technical Publication 06-1. Moss Landing Marine Laboratories. January 2006.

Karuppiah, M., \& Gupta, G. (1996). Impact of point and nonpoint source pollution on pore waters of two Chesapeake Bay tributaries. Ecotoxicology and Environmental Safety, 35, 81-85

Kemp, W. M., Boynton, W. R., Adolf, J. E., Boesch, D. F., Boicourt, W. C., Brush, G., Cornwell, J. C., Fisher, T. R., Glibert, P. M., Hagy, J. D., Harding, L. W., Houde, E. D., Kimmel, D. G.,
Miller, W. D., Newell, R. I. E., Roman, M. R., Smith, E. M., \& Stevenson, J. C. (2005). Eutrophication of Chesapeake Bay: Historical trends and ecological interactions. Marine Ecology Progress Series, 303, 1-29.

Ko, F., \& Baker, J. E. (2004). Seasonal and annual loads of hydrophobic organic contaminants from the Susquehanna River basin to the Chesapeake Bay. Marine Pollution Bulletin, 48, 840-851.

Langland, M., \& Cronin, T. (2003). A summary report of sediment processes in Chesapeake Bay and watershed. In Michael Langland, \& Tomas Cronin (Eds.), Water-Resources Investigations Report 03-4123. : USGS.

Magnuson, A., Harding, L. W., Jr., Mallonee, M. E., \& Adolf, J. (2004). Bio-optical model for Chesapeake Bay and the Middle Atlantic Bight. Estuarine, Coastal and Shelf Science, $61,403-424$

Miller, R. L., \& McKee, B. A. (2004). Using MODIS Terra $250 \mathrm{~m}$ imagery to map concentrations of total suspended matter in coastal waters. Remote Sensing of Environment, 93, 259-266.

Mobley, C. D., Stramski, D., Bissett, W. P., \& Boss, E. (2004). Optical modeling of ocean waters. Is the Case 1-Case 2 classification still useful? Oceanography, 17(2), 60-67.

Neckel, H., \& Labs, D. (1984). The solar radiation between 3300 and 12,500. Solar Physics, 90, 205-258.

North, E. V., Chao, S. -Y., Sanford, L. P., \& Hood, R. R. (2004). The influence of wind and river pulses on an estuarine turbidity maximum: Numerical studies and field observations in Chesapeake Bay. Estuaries, 27(1), 132-146.

Pan, X., Mannino, A., Russ, M. E., Hooker, S. B., \& Harding, L. W., Jr. (2010). Remote sensing of phytoplankton pigment distribution in the United States northeast coast. Remote Sensing of Environment, 114, 2403-2416.

Petus, C., Chust, G., Gohin, F., Doxaran, D., Froidefond, J., \& Sagarminaga, Y. (2010). Estimating turbidity and total suspended matter in the Adour River plume (South Bay of Biscay) using MODIS 250-m imagery. Continental Shelf Research, 30, 379-392.

Ramachandran, S., \& Wang, M. (2011). Near-Real-Time ocean color data processing using ancillary data from the Global Forecast System Model. IEEE Transactions on Geoscience and Remote Sensing, 49, 1485-1495.

Rodríguez-Guzmán, V., \& Gilbes-Santaella, F. (2009). Using MODIS 250 m imagery to estimate total suspended sediment in a tropical open bay. International Journal of Systems Application, Engineering and Development, 3(1).

Roman, M. R., Holliday, D. V., \& Sanford, L. R. (2001). Temporal and spatial patterns of zooplankton in the Chesapeake Bay Turbidity Maximum. Marine Ecology Progress Series, 213, 215-227.

Roman, M., Zhang, X., McGilliard, C., \& Boicourt, W. (2005). Seasonal and annual variability in the spatial patterns of plankton biomass in Chesapeake Bay. Limnology and Oceanography, 50(2), 480-492.

Ruffin, K. K. (1998). The persistence of anthropogenic turbidity plumes in a shallow water estuary. Estuarine, Coastal and Shelf Science, 47, 579-592.

Saenger, C., Cronin, T. M., Willard, D., Halka, J., \& Kerhin, R. (2008). Increased terrestrial to ocean sediment and carbon fluxes in the northern Chesapeake Bay associated with twentieth century land alteration. Estuaries and Coasts, 31, 492-500.

Sanford, L. P., Panageotou, W., \& Halka, J. P. (1991). Tidal resuspension of sediments in northern Chesapeake Bay. Marine Geology, 97, 87-103.

Stumpf, R. P. (1988). Sediment transport in Chesapeake Bay during floods: Analysis using satellite and surface observations. Journal of Coastal Research, 4(1), 1-15.

Stumpf, R. P., Arnone, R. A., Gould, R. W., Jr., Martinolich, P. M., \& Ransibrahmanakul, V. (2003). A partially coupled ocean-atmosphere model for retrieval of water-leaving radiance from SeaWiFS and coastal waters. NASA Technical Memorandum 2003-206892, Vol. 22. (pp. 51-59).

Tzortziou, M., Herman, J. R., Gallegos, C. L., Neale, P. J., Subramaniam, A., Harding, L. W., Jr., \& Ahmad, Z. (2006). Bio-optics of the Chesapeake Bay from measurements and radiative transfer closure. Estuarine, Coastal and Shelf Science, 68, 348-362.

Tzortziou, M., Sbramaniam, A., Herman, J., Gallegos, C., Neal, P., \& Harding, L. W., Jr. (2007). Remote sensing reflectance and inherent optical properties in the mid Chesapeake Bay. Estuarine, Coastal and Shelf Science, 72, 16-32.

Wang, M., SeungHyun, S., \& Shi, W. (2009). Evaluation of MODIS SWIR and NIR-SWIR atmospheric correction algorithms using SeaBASS data. Remote Sensing of Environment, $113,635-644$

Wang, M., \& Shi, W. (2005). Estimation of ocean contribution at the MODIS nearinfrared wavelengths along the east coast of the U.S.: Two case studies. Geophysical Research Letters, 32

Wang, M., \& Shi, W. (2007). The NIR-SWIR combined atmospheric correction approach for MODIS ocean color data processing. Optics Express, 15(24).

Warrick, J. A., DiGiacomo, P. M., Weisberg, S. B., Nezlin, N. P., Mengel, M., Jones, B. H., Ohlmann, J. C., Washburn, L., Terrill, E. J., \& Farnsworth, K. L. (2007). River plume patterns and dynamics within the Southern California Bight. Continental Shelf Research, 27, 2427-2448.

Werdell, P. J., Bailey, S. W., Franz, B. A., Harding, L. W., Jr., Feldman, G. C., \& McClain, C. R. (2009). Regional and seasonal variability of chlorophyll-a in Chesapeake Bay as observed by SeaWiFS and MODIS-Aqua. Remote Sensing of Environment, 113, 1319-1330.

Werdell, J. P., Franz, B. A., \& Bailey, S. W. (2010). Evaluation of shortwave infrared atmospheric correction for ocean color remote sensing of Chesapeake Bay. Remote Sensing of Environment, 114, 2238-2247.

Werdell, J. P., Franz, B. A., Bailey, S. W., Harding, L. W., Jr., \& Feldman, G. C. (2007). Approach for the long-term spatial and temporal evaluation of ocean color satellite data products in a coastal environment Coastal Ocean Remote Sensing. Proceedings of SPIE, 6680

Williams, M. R., Filoso, S., Longstaff, B. J., \& Dennison, W. C. (2010). Long-term trends of water quality and biotic metrics in Chesapeake Bay: 1986 to 2008. Estuaries and Coasts, 33, 1279-1299. 
Williams, M., Longstaff, B., Buchanan, C., Llansó, R., \& Dennison, W. (2009). Development and evaluation of a spatially-explicit index of Chesapeake Bay health. Marine Pollution Bulletin, 59, 14-25.

Wright, D., Schaffner, L. C., \& Maa, J. P. -Y. (1997). Biological mediation of bottom boundary layer processes and sediment suspension in the lower Chesapeake Bay. Marine Geology, 141, 27-50.
Yarbro, L. A., Carlson, P. R., Fisher, T. R., Chanton, J. P., \& Kemp, W. M. (1983). A sediment budget for the Choptank River estuary in Maryland, U.S.A.. Estuarine, Coastal and Shelf Science, 17, 555-570.

Yeager, C. L. J., Harding, L. W., Jr., \& Mallonee, M. E. (2005). Phytoplankton production, biomass and community structure following a summer nutrient pulse in Chesapeake Bay. Aquatic Ecology, 39, 135-149. 